\title{
Low cost drinking water technology - rainwater harvesting with solar purification
}

\author{
Shivam D. Patange, Nandini Nimbkar and Anil K. Rajvanshi*
}

As a result of scarcity and deteriorating quality of drinking water especially in rural India, more attention is being paid to rainwater harvesting. A very simple and low cost drinking water technology (DWT) has been developed which uses appropriate rainwater harvesting methodology and solar purification. The costliest item in DWT is the storage tank. A possible mechanism for reducing this cost by the government of India scheme has been indicated in the article. With cost reduction, this DWT can become a viable and economical solution for potable water in rural households.

Keywords: Escherichia coli, drinking water technology, rainwater harvesting, solar water purifier.

SINCE the population and economy of India are growing at a phenomenal rate, the water availability per capita is declining exponentially ${ }^{1}$. Discharge of untreated domestic/municipal wastewater has resulted in contamination of $75 \%$ of all surface water across India making it unsafe to drink $^{2}$. Rural population in India in 2017 , according to the World Bank data, was reported as $66.46 \%$. To provide clean water for drinking, cooking and other domestic use to every rural household, the government of India launched the National Rural Drinking Water Programme (NRDWP) in 2009. Despite allocating large amount of funds, the programme failed to achieve its targets due to poor implementation ${ }^{3}$. The country faces a huge burden of deaths caused by water-borne diseases; acute diarrhoeal diseases being the top killer ${ }^{4}$. Alongside water quality, quantity of drinking water is also reducing due to overexploitation. India is the largest consumer of groundwater in the world with an estimated usage of $230 \mathrm{~km}^{3}$ per year ${ }^{5}$. Lowering of groundwater table has resulted in saline water intrusion in many parts of the country, especially along the coastline ${ }^{6}$. As nearly $85 \%$ of the rural population uses groundwater for drinking purposes, a vast population is threatened by the health hazard created by the presence of fluoride, nitrate, iron and arsenic in the water ${ }^{7}$.

As a result of scarcity and deteriorating quality of drinking water, especially in rural India, more attention is being paid to rainwater harvesting $(\mathrm{RWH})$. It prevents soil erosion and floods by diverting run-off water from roof into storage tanks. Besides, it lowers the pressure on the groundwater and reduces energy required for pumping it.

Nevertheless, one of the important issues often observed with rainwater for potable use is its microbiological

\footnotetext{
The authors are in the Nimbkar Agricultural Research Institute, Phaltan 415 523, India.

*For correspondence. (e-mail: anilrajvanshi@gmail.com)
}

contamination $^{8-10}$. The contamination is due to air-borne microorganisms, bird and animal droppings on the roof, and windblown dust. Though many studies on quality of rainwater are continuing, less attention is being paid on finding economical ways for treating collected rainwater to make it potable.

Studies on RWH for potable use rely on expensive UV filter $^{11}$ or chlorine disinfectant ${ }^{12}$. Excess chlorine in drinking water has health-associated risks ${ }^{13}$. The use of solar collector disinfection for rainwater purification has also been studied. In this method a wooden box containing two-litre polyethylene terephthalate bottles filled with contaminated water and fortified with food preservatives such as lemon juice and vinegar was exposed to the sun for four to eight hours both on clear and cloudy days ${ }^{14}$. Studies have shown that bisphenol-A (BPA) from plastic bottles gets leached into water at elevated temperatures, thus making treated water unsafe for drinking ${ }^{15}$. The other purifiers (membrane filters) available in the market need electricity and periodic filter replacement which render them uneconomical for most of the rural poor from developing countries who additionally may not have access to electricity.

We present in this article, a low-cost drinking water technology (DWT) which collects rainwater, cleans it and purifies it using solar energy. The technology consists of three parts: (a) Rooftop rainwater harvesting; (b) Cleaning of rainwater of its debris and suspended material; (c) Removing microbiological contaminants via solar purification.

\section{Rooftop rainwater harvesting system}

There are three basic components involved in RWH, viz. rainwater catchment, conveying channels and water storage tank. 
Catchment consists of the roof from where the incoming rainwater is conveyed to the storage tank via conveying/collection channels. In India, various types of roofing materials are used. Most of the old dwellings had thatched roof which is becoming less common because other types of roofing materials like sheet metal, tiles, etc. are cheaper and more durable. Besides, the installation of RWH structures for households having nonthatched roofs is easier. Nevertheless for old thatched roofs, a tarpaulin or waterproof plastic sheet can be used to make the roofs impermeable so that rainwater collection can be simplified. In India, majority of the rural dwellings have only one room and data of average roof size in rural settings was not available ${ }^{16}$. However, as per the building norms, minimum habitable area required for a family of 5 is 9.5 square metres ${ }^{17}$.

Based on building norms and roof material of dwellings, a RWH system was installed on the campus of the Nimbkar Agricultural Research Institute (NARI) for a single room dwelling having $12 \mathrm{~m}^{2}$ roof area and corrugated GI as roof material. As Phaltan falls in a droughtprone region and receives around $500 \mathrm{~mm}$ of annual rainfall $^{18}$, calculations showed that the selected roof area was sufficient to meet annual drinking water demand of a typical family of five members (daily water consumption of 10-15 1). Figure 1 shows the actual RWH system installed on a single room dwelling.

Semi-circular PVC pipes which are readily available in the market were used as collection channels. For the present RWH system, the channel size was selected based on maximum rainfall intensity at Phaltan. A stainless steel (SS) coarse mesh was used to prevent the entry of leaves into the downpipe. This mesh needs to be cleaned regularly (once a month) in areas where dwellings are in the vicinity of tree cover. Cloth filter tied at the tank

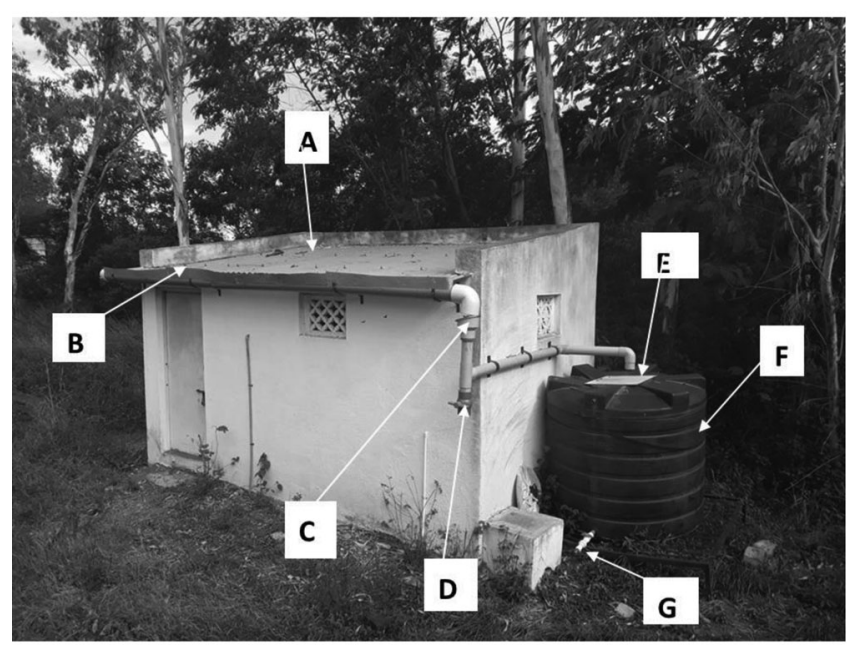

Figure 1. Installed RWH setup for an average-sized dwelling. A, Corrugated GI roof; B, Collection channel; C, SS mesh screen; D, First rainwater diverter valve; E, Cloth filter; F, Storage tank; G, Tap for drawing rainwater. entrance further cleaned the water by filtering small particles. It also helped in preventing mosquito breeding inside the tank. The cloth filter has to be cleaned once before every rainy season. Small gradient was provided to the water collection channel so that there is no stagnant water left in it for the mosquitoes to breed.

A readily available $30001 \mathrm{PVC}$ storage tank was used based on daily drinking water consumption of a family and distribution of rainfall throughout the year in Phaltan region. Storage tank accounts for more than $70 \%$ of the cost of the RWH system. The storage tank should be big enough to store water required for the whole year and it should be cleaned thoroughly with disinfectant before every rainy season.

The water from this PVC tank will be used year round for potable purposes. Almost all the types of plastic products available in the market leach some chemicals and there are indications that they may have adverse health effects ${ }^{19}$. Very little data is available on the effect of water stored for a long time in PVC tanks made of highand low-density polyethylene (HDPE-LDPE), polypropylene (PP) and fibreglass-reinforced plastic (FRP).

Due to the high capital cost and no financial support from the government, small-sized water tanks are often used which leads to substantial rainwater loss. RWH will not be economical for rural poor unless some form of financial assistance for purchasing storage tank is available. There is a need to develop a mechanism by which direct transfer of money into the beneficiary's account is possible. 'Water for All' is the government of India's flagship programme for providing water in rural areas ${ }^{20}$. Under this programme, it is estimated that INR 5,000 to 10,000 crores/year have been spent and very little progress can be seen on the ground. We feel that helping each rural household for installation of RWH system will be a more effective usage of these funds.

Another reason for RWH not being very popular is the low efficiency of water collection. This is mainly due to not taking into consideration annual rainfall in the region, maximum rainfall intensity and roof area available when designing the RWH system. Consequently, considerable quantity of rainwater is lost due to spillage and only a fraction of the total rainwater received is collected. In our case the collection efficiency was improved by designing RWH system based on rainfall and roof size; providing proper alignment between the catchment and collection channel, and stoppers to avoid water spillage during torrential rainfall. In the 2019 rainy season, the water collection efficiency of the installed RWH system was $82 \%$. Efforts are being made to further increase this efficiency.

\section{Colour removal}

Although rainwater is free of salts and other harmful chemicals like arsenic, it gets contaminated with 
windblown dust, animal droppings, leaves and decayed organic matter on the roof. The suspended and dissolved matter causes water colouration. Iron and manganese cause red-brown to black colour and organic matter imparts brown-yellow colour to the water ${ }^{21}$. The rainwater collected from RWH system installed at NARI was found to be brownish. Different techniques like sedimentation, microfiltration and coagulation/flocculation were tried to make the collected rainwater colourless.

For sedimentation, the collected rainwater was kept in a flask for $24 \mathrm{~h}$ and checked for colour removal. In microfiltration, the rainwater was passed through either a 150 micron sieve or an 11 micron Whatman filter. For coagulation, alum, poly-aluminium chloride (PAC) and drumstick seed powder were added in different amounts to the rainwater. Light transmission tests via a spectrophotometer were performed to determine the effectiveness of the coagulants. Alum was found to be the most effective and economical coagulant for colour removal. In addition to colour removal, alum was also seen to inactivate somewhat coliform bacteria by coagulating them into a slurry ${ }^{22}$. Effectiveness of a coagulant depends on the $\mathrm{pH}$ of the dosed water and as the $\mathrm{pH}$ of collected rainwater (range 6.0 to 6.5 ) was in the working $\mathrm{pH}$ range of alum $(5.8-6.5)^{23}$, it seems to be more effective than the other coagulants. Figure 2 shows the comparison of treated and untreated rainwater with tap water.

\section{Removal of microbiological contaminants}

A well-known WHO protocol of coliform count (most probable number (MPN) technique) was followed for the microbiological study ${ }^{24}$. The rainwater contains airborne microorganisms and hence it is not suitable for immediate drinking $^{25}$. Microbiological testing of collected rainwater (on our campus) gave a coliform count (MPN) of 1600. Heating rainwater via a biomass stove can help in killing dangerous pathogens and bacteria. However due to

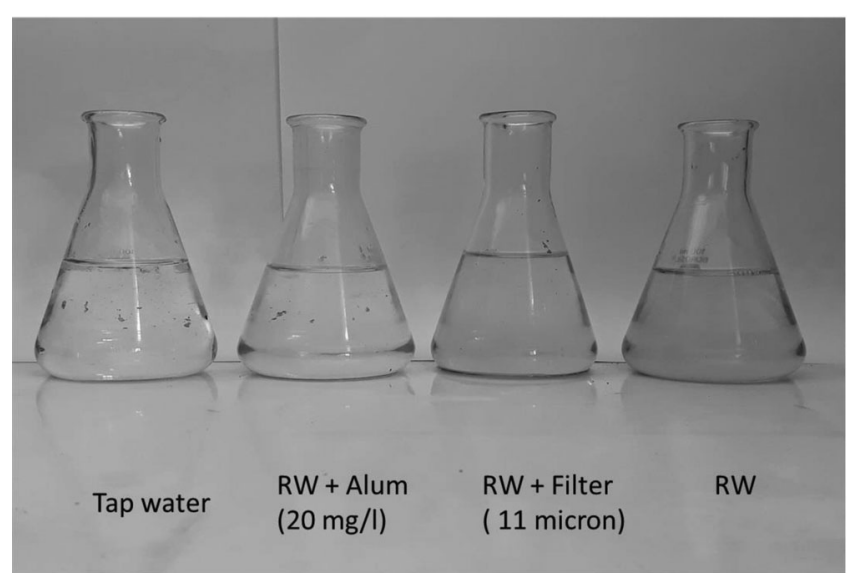

Figure 2. Comparison of treated and untreated rainwater with tap water. poor efficiency of these stoves, it requires huge amount of energy (to boil 11 of water requires about $1 \mathrm{kWh}$ of energy $)^{26}$. In addition, the biomass stove produces tremendous indoor air pollution and is the cause of death of around 4 million people across the globe ${ }^{27}$.

Solar water purifier (SWP) developed by NARI is nonpolluting, user-friendly and heats the water using available solar energy to make the water potable ${ }^{28}$. Figure 3 shows a family size SWP used in this study. It consists of four tubular collectors attached to a manifold. These tubular solar collectors are basically thermos flasks with high solar collection efficiency (greater than 92\%) ${ }^{29}$. SWP works on the principle of stagnant water temperature. During the day solar energy heats the water in tubular solar collectors. As the absorption efficiency of these tubular collectors is high, even on a completely overcast day the temperature reaches $45^{\circ} \mathrm{C}$ for more than $3 \mathrm{~h}$ which is adequate to inactivate all coliforms.

Figure 4 shows the graph of MPN count of rainwater vs temperature of water in a solar tubular collector at $3.30 \mathrm{pm}$. The water reaches its maximum temperature at $3.30 \mathrm{pm}$ and retains its heat for another $3-4 \mathrm{~h}$, due to the excellent insulation of the tubular collector.

Tests have shown that SWP inactivates the coliforms whenever water temperature reaches $45^{\circ} \mathrm{C}$ for three hours ${ }^{28}$. At higher temperatures, less time is required for inactivation of coliforms. From temperature recordings (Figure 5) it was observed that from July 2019 to October 2019, water temperature in SWP dropped below $45^{\circ} \mathrm{C}$ only on seven days. Previous study had shown that throughout the year the water temperature above $45^{\circ} \mathrm{C}$ was obtained $99 \%$ of the time ${ }^{28}$. Thus SWP works efficiently year around.

The experiments were performed from July to October because in Phaltan region cloud cover is maximum in these months. Every day 151 of rainwater was taken from the storage tank, known quantity of alum $(20 \mathrm{mg}$ of alum per litre of water, i.e. $0.002 \%$ on $\mathrm{w} / \mathrm{w}$ basis) was added to

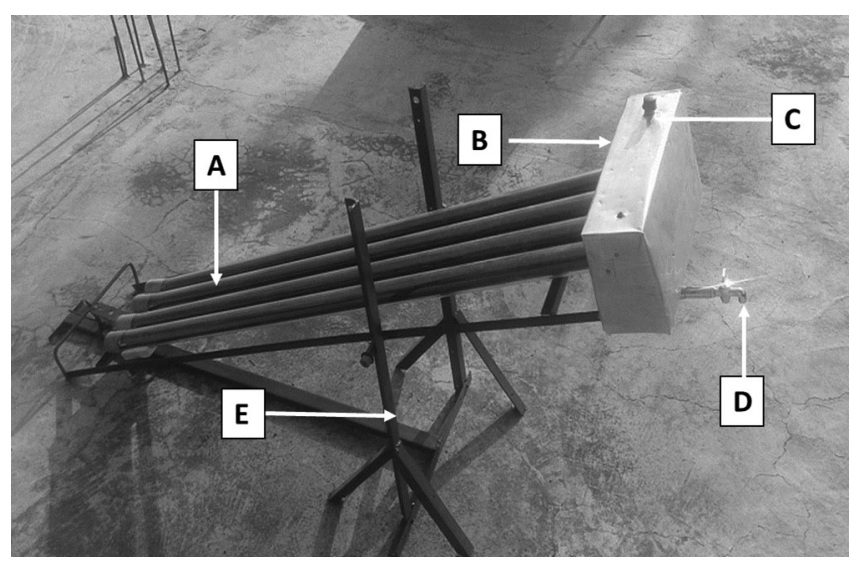

Figure 3. Four-tube solar water purifier. A, Tubular solar collectors; B, Stainless steel manifold; C, Inlet port; D, Tap (outlet port); E, Supporting mild steel frame. 
it and the clean water (free of settled slurry) was put into SWP which was set on the roof top of NARI building. Figure 6 shows the schematic of DWT. Also, the temperature of water was recorded at $3.30 \mathrm{pm}$. Next day morning

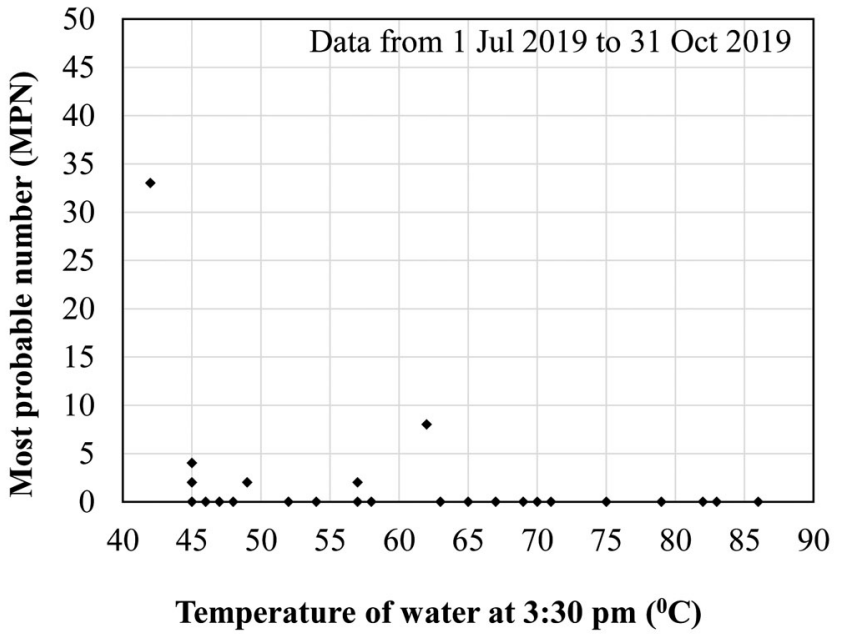

Figure 4. Coliform count (MPN) for rainwater versus maximum water temperature in tubular collector.

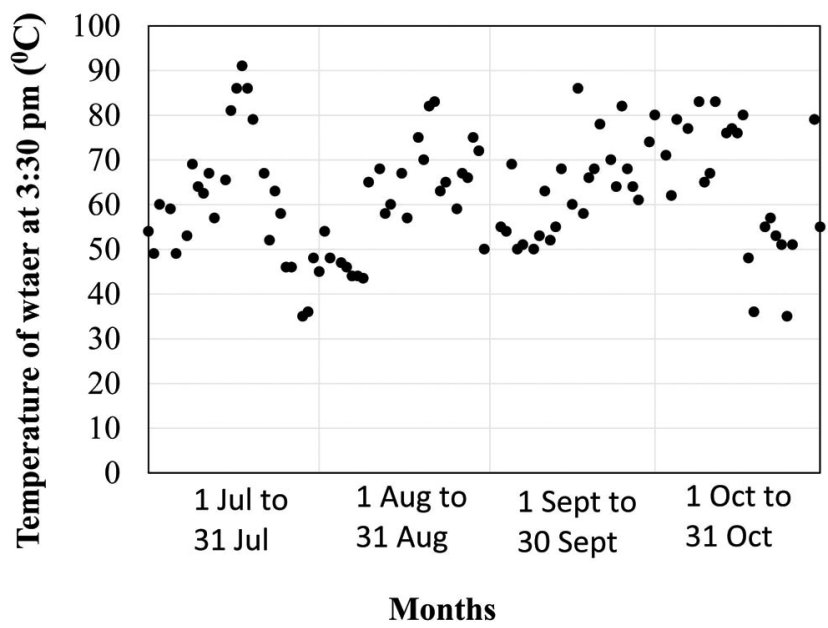

Figure 5. SWP water temperature at $3.30 \mathrm{pm}$ from July to October 2019.

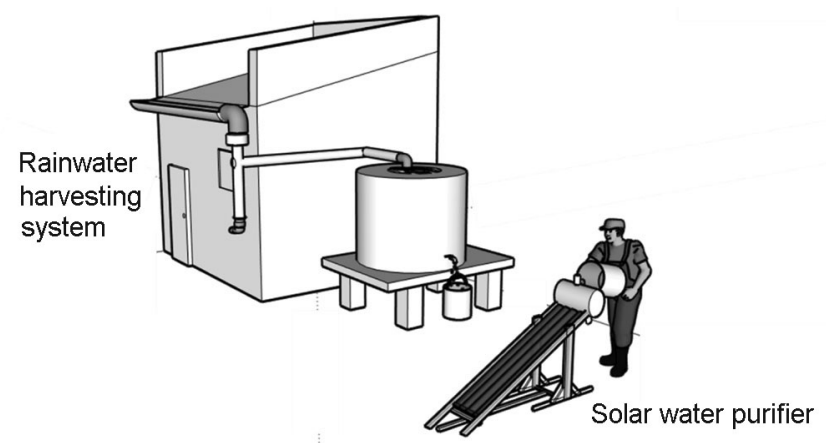

Figure 6. Schematic of drinking water technology. the water was taken out from the SWP and subjected to microbiological testing to measure the coliform count (MPN).

Normally rainwater harvesting is done to use it as grey water; mainly for industrial uses, gardening and cleaning. We feel that the DWT solution described in this paper offers a simple and economical solution to enable the use of RWH for potable purposes.

\section{Conclusions and future plan}

A very simple and low-cost drinking water technology has been developed which uses appropriate rainwater harvesting methodology and solar purification. The costliest item in DWT is the storage tank. A possible mechanism for reducing this cost by the government of India scheme has been indicated in the article. With cost reduction, this DWT can become a viable and economical solution for potable water in rural households.

We feel that this DWT should be implemented for rural schools. Efforts are on to put a few such systems on trial basis in these schools. These schools are a good place for DWT because:

(i) Children are more vulnerable to water-borne diseases and hence should be given pure drinking water. Drinking water from 10 rural schools (in the vicinity of NARI campus) showed high coliform count (MPN) ranging from 240 to 1800 . Most of them had RO and other type of filters which were never changed or replaced resulting in the high MPN count.

(ii) Children will learn about RWH and solar energy through this DWT as they will operate the system. It is hoped that this exposure will help them educate their parents about it and may start DWT revolution in rural areas.

(iii) The roof area of most of the rural schools is sufficient to carry out RWH for drinking water during school duration (10 months) and thus the installation of this DWT in schools makes sense ${ }^{30}$.

1. Bhat, T. A., An analysis of demand and supply of water in India. J. Environ. Earth Sci., 2014, 4(11), 67-72.

2. Ministry of Urban Development (MoUD), National Urban Sanitation Policy, 2009.

3. Suhag, R., CAG Audit Report Summary: National Rural Drinking Water Programme, PRS Legislative Research, New Delhi, 2018.

4. Khambete, A. K., When water kills, Indian Water Portal, 2019.

5. WHO, India groundwater: a valuable but diminishing resource, WHO, 2012.

6. Central Ground Water Board, Ground water quality scenario in India, Government of India, 2015.

7. World Bank, Deep wells and prudence: towards pragmatic action for addressing groundwater overexploitation in India, 2010.

8. Karim, M., Microbial contamination and associated health burden of rainwater harvesting in Bangladesh. Water Sci. Technol., 2010, 61(8), 2129-2135; doi:https://doi.org/10.2166/wst.2010.031. 
9. Hamilton, K. et al., A global review of the microbiological quality and potential health risks associated with roof-harvested rainwater tanks. NPJ Clean Water, 2019, 2(7); doi:https://doi.org/10.1038/ s41545-019-0030-5.

10. Sánchez, A. S. et al., A review on physicochemical and microbiological contamination of roof-harvested rainwater in urban areas. Sustain. Water Qual. Ecol., 2015, 6, 119-137; doi:https://doi. org/10.1016/j.swaqe.2015.04.002.

11. Yongkyun, K. et al., Community-based rainwater harvesting (CBRWH) to supply drinking water in developing countries: lessons learned from case studies in Africa and Asia. Water Sci. Technol.: Water Supp., 2016, 16(4), 1110-1121; doi:https://doi.org/10.2166/ ws.2016.012.

12. Jean-Marc Mwenge Kahinda et al., Domestic rainwater harvesting to improve water supply in rural South Africa. Phys. Chem. Earth, 2007, 32, 1050-1057; doi:https://doi.org/10.1016/j.pce.2007.07.007.

13. WHO, Chlorine in Drinking-water, World Health Organization, 2003.

14. Amin, M. T. et al., Improvement of solar based rainwater disinfection by using lemon and vinegar as catalysts. Desalination, 2011, 276(1-3), 416-424; doi:https://doi.org/10.1016/j.desal.2011.03.076.

15. Borde, P. E. et al., Community challenges when using large plastic bottles for solar energy disinfection of water (SODIS). BMC Public Health, 2016, 16, 931.

16. Government of India Census, Households by predominant material of roof of census houses occupied by them, Ministry of Home Affairs, Government of India, 2011.

17. Ministry of Urban Development, Model Building By-Laws, Government of India, 2016.

18. Rajvanshi, A. K. et al., Long Term Weather Trends in Phaltan, Maharashtra, 2006; https://nariphaltan.org/weather.pdf

19. Ang, C. Z. et al., Most plastic products release estrogenic chemicals: a potential health problem that can be solved. Environ. Health Perspect., 2011, 119(7), 989-996; doi:https://dx.doi.org/ $10.1289 \% 2$ Fehp. 1003220 .

20. Vaishnav, A., Demand for Grants 2019-20 Analysis: Drinking Water and Sanitation, PRS Legislative Research, 2019.

21. Clean Water Team, Color of Water Fact Sheet, State Water Resources Control Board, 2009.
22. Bulson, C. P. et al., Removal and inactivation of bacteria during alum treatment of a lake. Appl. Environ. Microbiol., 1984, 48(2), $425-430$

23. Peter, G., An Operator's Guide to Water Treatment Coagulants, 31st Annual Qld Water Industry Workshop, Rockhampton, 2006, pp. 14-20.

24. WHO, In Water Quality Monitoring - A Practical Guide to the Design and Implementation of Freshwater Quality Studies and Monitoring Programmes, UNEP/WHO, 1996.

25. Kaushik, R. et al., Microbial quality and phylogenetic diversity of fresh rainwater and tropical freshwater reservoir. PLoS ONE, 2014, 9(6): e100737; doi:https://dx.doi.org/10.1371\%2Fjournal. pone. 0100737 .

26. Geller, H. S., Fuel efficiency and performance of traditional and innovative cookstoves. Proc. Indian Acad. Sci. Eng. Sci., 1982, 5, 373-393.

27. WHO, Household air pollution and health, World Health Organization, 2018.

28. Rajvanshi, A. K. et al., Low-cost solar water purifier for rural households. Curr. Sci., 2018, 115(1), 32-34.

29. Ministry of New and Renewable Energy, MNRE standard: All glass (glass in glass) evacuated solar collector tubes, MNRE, 2013.

30. ISI, Recommendations for Basic Requirements of School Buildings, Indian Standards Institution, New Delhi, 1978.

ACKNOWLEDGEMENTS. We thank the Bajaj group for providing CSR funds for fellowship to SP and to carry out this research. We thank Subhash Lakhotia, Noorie Rajvanshi, K. S. Jayaraman among others for providing useful suggestions. We also thank A. D. Nale and A. M. Pawar (technicians) for their help in setting up RWH unit for an average sized dwelling.

Received 28 November 2019; accepted 7 January 2020

doi: $10.18520 / \mathrm{cs} / \mathrm{v} 118 / \mathrm{i} 6 / 872-876$ 